\title{
IGF-I, IGF-binding protein-3 and breast cancer risk
}

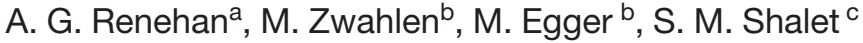

${ }^{a}$ Department of Surgery, Christie Hospital NHS Trust, Manchester, UK; ${ }^{b}$ Department of Social and Preventive Medicine, University of Berne, Berne, Switzerland; ' ${ }^{\circ}$ Department of Endocrinology, Christie Hospital NHS Trust, Manchester, UK.

\begin{abstract}
Insulin-like growth factor I (IGF-I) and its main binding protein 3 (IGFBP-3) are multi-regulatory peptides important in tumour cell growth and survival. In the circulation, they occur in large quantities and are readily measured. Across a population, concentrations vary and this may impact on risk of cancers common in western societies. Emerging epidemiological evidence supports the notion that higher levels of IGF-I are associated with increased risk of pre-menopausal, but not post-menopausal, breast cancer. Higher levels of IGFBP-3 may also predict for increased risk of pre-menopausal breast cancer, but this is contrary to the conventional view that this peptide is tumour protective. Nutritional and lifestyle factors, important in breast cancer risk, also inter-relate with circulating levels of IGF-I, but in many circumstances, the relationships are complex. It is becoming increasingly important that the clinical breast oncologist understands the physiology of the IGF system and its potential role in cancer risk assessment and prevention.
\end{abstract}

Keywords: Insulin-like growth factor; Breast cancer risk; Cancer prevention; Systematic review; Tumorogenesis; Peptides

\section{Introduction}

Insulin-like growth factor I (IGF-I) and its main binding protein 3 (IGFBP-3), are both growth hormone (GH) dependent regulatory peptides, and together are referred to as the GH-IGF-I axis [1]. Both peptides are involved in cell growth and survival, and thus, have been implicated in tumour development [2]. Unlike many other growth factors, they exhibit both classical hormonal characteristics and local tissue influences, occur in large quantities in the circulation, and are readily measured. There are wide interindividual variations in IGF-I and IGFBP-3 concentrations, and it is speculated that this variability may influence the distribution of cancer risk in a population

Correspondence to: Dr Andrew Renehan, Department of Surgery, Christie Hospital NHS Trust, Wilmslow Road, Manchester M20 4BX, UK. E-mail: arenehan@picr.man.ac.uk; Tel: +0161 446 3363; Fax: +0161 4463772

Publication date 28/01/05

BCO/300/2004/FO
$[3,4]$. Over recent years, there has been mounting evidence supporting the hypothesis that circulating levels of IGF-I and IGFBP-3 influence development of common cancers within western societies, of which breast cancer is well documented.

This review will focus on the epidemiological evidence linking circulating IGF-I, IGFBP-3 and breast cancer risk, and highlight specific recent developments relevant to the potential role of these biomarkers in cancer risk assessment and prevention. There are several complex relationships between the IGF system and other risk factors for breast cancer such as oestrogens and hormonal replacement therapy [5], diet and energy intake [6,7], excess body weight $[8,9]$ and physical activity [10], but these are dealt with elsewhere as referenced. The IGF physiology and biological mechanisms relevant to cancer development will be summarized, but thorough dissertations of these areas are beyond the scope of this review. The potential role of the IGF-I receptor 


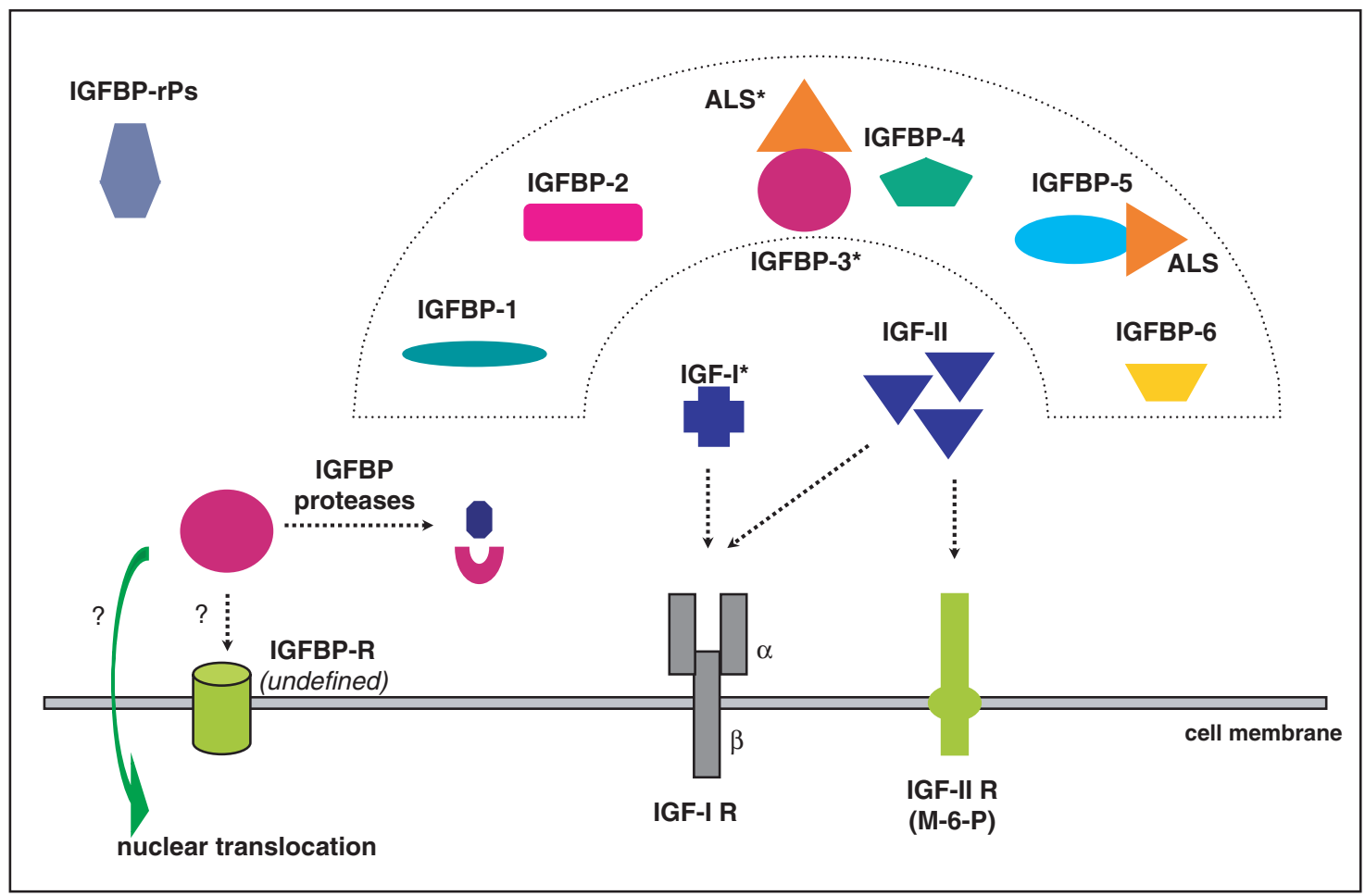

* GH-dependent

Figure 1.

Schematic diagram of the IGF system. M-6-P: mannose-6-phosphate.

as a therapeutic target is also beyond this review, and dealt with elsewhere $[11,12]$.

\section{Physiology of the IGF system}

The IGF system is a complex molecular network which includes two ligands (IGF-I and IGF-II), two receptors (IGF-IR and IGF-IIR or mannose-6-phosphate receptor), six high-affinity-binding proteins (IGFBP-1-6), at least four low-affinity IGF binding-protein-related peptides (IGFBPrP-1-4), and several binding-protein proteases [13-15] (Fig. 1). The major form of binding protein in human circulation is IGFBP-3 [16]. Unlike the other IGF-binding proteins, IGFBP-3 is typically fully saturated, and in the human circulation, exists with the IGF ligands and an acid-labile subunit (ALS) in the form of a 150-kDa ternary complex [17]. Thus, circulating IGF-I exists in three pools: ternary complex (70-80\%); a 50-kDa IGFBP pool (20-25\%); and free IGF-I $(<5 \%)$ [15]. Under normal conditions, total IGF-I and IGF-II, and total IGFBP-3 in serum are in equimolar concentrations [18] (Fig. 2).

IGF-I, IGF-II and the IGF-binding proteins occur in large quantities in the circulation and are readily measured. In addition to being GH dependent, IGF-I and IGFBP-3 are influenced by age (mean levels of both peptides decline with age after puberty) [19], gender (mean levels of IGF-I are higher in men; mean levels of IGFBP-3 are higher in women) [20], and nutritional status (calorie restriction is associated with profound reduction in serum IGF-I concentrations) [21].

\section{IGF-I and IGFBP-3: biological actions and tumour development}

IGF-I and IGFBP-3 may influence tumour development at many levels, and through mechanisms dependent and independent of the IGF-I receptor (IGF-IR) as summarized in Box 1.

Comprehensive reviews of the biological actions of IGF-I and IGFBP-3 in relation to tumour development can be found elsewhere $[2,28,42]$, but are summarized here.

\section{IGF-1 and tumorogenesis}

Several cellular actions of IGF-I favour tumour growth, including mitogenesis, antiapoptosis, induction of vascular endothelial growth factor (pro-angiogenesis) and increased cell migration. In addition, IGF-I stimulates pathways key to early tumour initiation (e.g. beta-catenin) [43] and potentiates the effects of other cell growth stimulants including oestrogens [44]. 

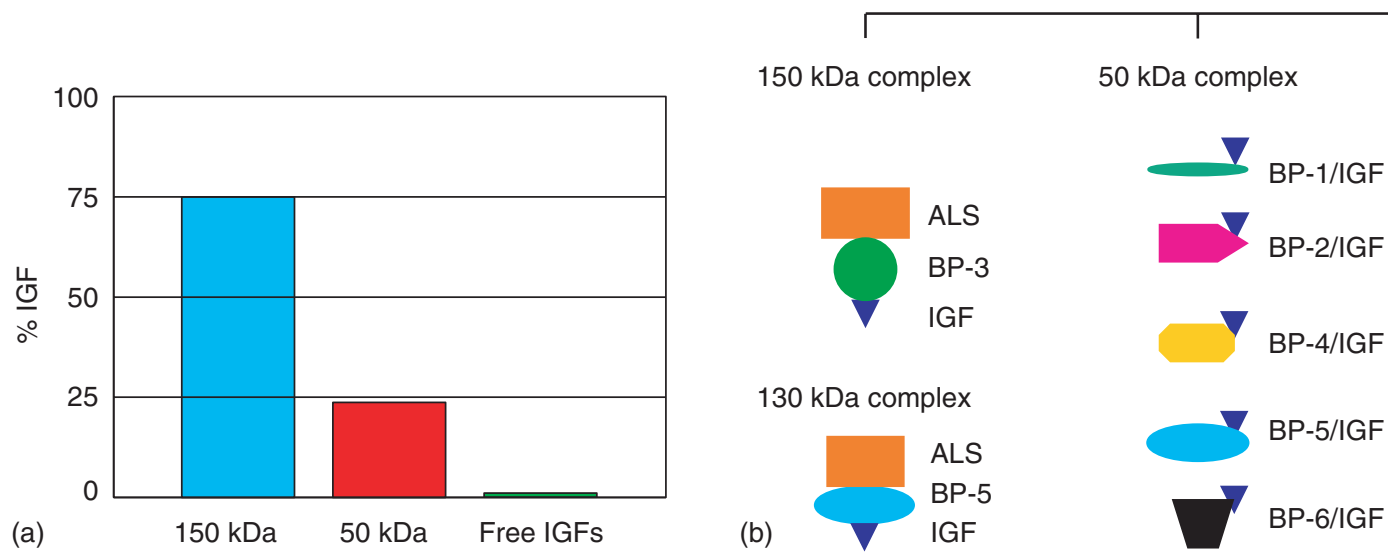

Figure 2.

The various IGF pools in human serum and IGF-IGFBP complexes. (a) The relative distribution of IGFs between $150,50 \mathrm{kDa}$ and the free pool. (b) Proposed model of the forms in which IGFs circulate in human serum. Within the complexes IGF = $\alpha$-subunit, IGFBP $=\beta$-subunit and $A L S=\delta$-subunit.

Box 1: Biological actions of IGF-I and IGFBP-3, and tumorogenesis.

\begin{tabular}{|c|c|}
\hline & Comments \\
\hline \multicolumn{2}{|l|}{ IGF-I ligand } \\
\hline Mitogenesis & Almost ubiquitous action in human cells [22] \\
\hline Anti-apoptosis & $\begin{array}{l}\text { Potent inhibitor of apoptosis induced by gamma radiation, cytotoxic agents (e.g. etoposide) } \\
\text { and TNF [23] }\end{array}$ \\
\hline Pro-angiogenesis & Induces hypoxia-inducible factor 1-mediated VEGF production [24] \\
\hline Cell migration & In cooperation with integrins and E-cadherin [25] \\
\hline Cell adhesion & Beta-catenin pathway initiation [26] \\
\hline Interactions with ER & Synergistic in cell proliferation [27] \\
\hline \multicolumn{2}{|l|}{ IGFBP-3 } \\
\hline Growth inhibitory & (In theory) through high-affinity sequestration of IGF ligands [28] \\
\hline Anti-proliferation & IGFBP-3 may bind IGF-I receptor and inhibit IGF-I action $[29,30]$ \\
\hline Potentiation of apoptosis & Potentiates ceramide-induced apoptosis in Hs578T breast cancer cells [31] \\
\hline Anti-apoptosis & Independent of IGF-I receptor [32,33] \\
\hline ECM interactions & Interacts with fibronectin $[34,35]$ and glycosaminoglycans [36] \\
\hline $\begin{array}{l}\text { Interactions with signal pathways } \\
\text { p53 interaction }\end{array}$ & $\begin{array}{l}\text { TGF-beta signalling [33], retinoid X receptor [37] and epidermal growth factor signalling [38] } \\
\text { p53 activation induces IGFBP-3 production [39] }\end{array}$ \\
\hline Influences pro-apoptotic proteins & Modulates expression of pro-apoptotic proteins, Bax and Bcl-2 $[40,41]$ \\
\hline
\end{tabular}

TNF: tumour necrosis factor; VEGF: vascular endothelial growth factor; ER: oestrogen receptor; ECM: extracellular matrix; TGF: transforming growth factor.

The effects of IGF-I are mediated through IGF-IR, a tyrosine kinase receptor. Most breast cancer cell lines (notable exception is Hs578T) express functional IGF-IRs, though unlike other cancers, IGF-IR expression is seldom increased $[45,46]$. IGF-IR stimulation influences signalling through other receptors such as the HER/neu receptor, thought to be important for the inhibitory effects of trastuzumab [47]. The IGF-IR signalling pathways are complex and not fully understood, and reviewed elsewhere $[48,49]$. The predominant mitogenic and apoptotic signalling molecule activated by oestrogen receptor (ER) positive cells is insulin receptor substrate-I (IRS-I), which activates downstream networks including phosphaditidylinositol
(PI) 3 kinase and the mitogen activating protein (MAP) kinase pathways.

\section{IGFBP-3 and tumorogenesis}

At a cellular level, IGFBP-3 is multi-functional having actions that may favour and/or inhibit tumour growth $[28,40]$. Conventionally, co-treatment of IGF-I and the binding protein causes IGFBP-3 to inhibit IGFmediated effects via high-affinity sequestration of the ligand, leading to the prevention of IGF-induced IGF-IR auto-phosphorylation and signalling - this is the IGF-dependent effect. It is becoming increasingly clear that, apart for modulation of IGF actions, 
IGFBP-3 may exert intrinsic bio-activity either in the absence of IGFs (IGF-independent effects) or in the presence of IGFs without triggering IGF-IR signalling (IGF-IR-independent effects) [28]. In addition, IGFBP-3 action may be modulated through proteolytic enzymes, and in turn, the cleaved IGFBP-3 fragments may either potentiate or inhibit tumour growth [50]. Paradoxically, IGFBP-3 may also inhibit IGF-IR activation independent of IGF-I [30].

On balance, most in vitro studies show that IGFBP-3 is tumour inhibitory, but it is possible that in some circumstances, resistance develops to the inhibitory effects of IGFBP-3, or alternatively, a more appropriate model of in vivo action may be an anchorage-dependent system, in which IGFBP-3 demonstrates anti-apoptotic (tumour favouring) characteristics [34]. A further dimension is that tissue expression of IGFBP-3 in the presence of excess circulating IGFBP-3 may be organ dependent [51].

\section{Epidemiological studies}

In 1998, in a seminal paper from the Health Professional's study, Chan et al. showed that IGF-I levels in prospectively collected plasma positively predicted, while IGFBP-3 levels negatively predicted for the development of prostate cancer [52]. Further studies on breast [53], colorectal [54], and lung [55] cancer risk substantiated these observations, and a hypothesis emerged that circulating IGF-I levels are positively associated, whereas IGFBP-3 levels are inversely associated with cancer risk. However, the results from some studies were inconsistent, and the present authors felt that there was a need for a better understanding of the reasons underlying heterogeneous results, including differences between cancer sites, study populations and designs, and assay characteristics. We addressed these questions in a systematic review and meta-regression analysis published recently in the Lancet [56]. A summary of this comprehensive analysis and its potential implications are the focus of the remainder of this review.

\section{Systematic review and meta-regression analysis}

Our systematic review [56] was conducted using Cochrane methodology and reported in accordance with QUORUM recommendations [57]. In particular, the search (to December 2002), inclusion criteria and sub-group analyses were performed based on a pre-study protocol and a priori hypotheses. In addition, sensitivity analyses were performed at several levels (mainly using meta-regression methods) to explore for sources of heterogeneity and confounding. We considered cohort and case-control studies if they reported analyses of the relationships between measurements of circulating IGF-I and/or IGFBP-3 and invasive cancer. For breast cancer, the analysis considered pre- and post-menopausal breast cancers separately, excluding reports on 'all invasive breast cancers'.

Six studies [53,58-62] on breast cancer fulfilled inclusion criteria (Table 1). In meta-analyses performed - using random-effects methods [63] comparing uppermost vs. lowermost categories, IGF-I was associated with pre-menopausal (odds ratio $(\mathrm{OR})=1.93,95 \%$ confidence interval $(\mathrm{Cl})$ : 1.38-2.69, $P<0.001$ ) but not post-menopausal breast cancer (Table 2). The analysis for IGFBP-3 was based on five studies, as the study of Hankinson et al. [53] did not report associations for IGFBP-3. Comparing uppermost vs. lowermost categories, IGFBP-3 was positively and significantly associated with pre-menopausal breast cancer $(\mathrm{OR}=1.93$, $95 \% \mathrm{Cl}: 1.28-2.99, P=0.002)$.

We recognized that studies differed in reporting risk using different categories (tertiles to quartiles). To address this, we calculated study-specific dose-response slopes incorporating data between

Table 1. Characteristics of the six breast cancer studies meeting inclusion criteria*.

\begin{tabular}{|c|c|c|c|c|c|c|}
\hline Authors & Country & Study design & Case/control & Sample medium & $\begin{array}{l}\text { IGF-I } \\
\text { measurements }\end{array}$ & $\begin{array}{l}\text { IGFBP-3 } \\
\text { measurements }\end{array}$ \\
\hline Del Giudice et al. [58] & Canada & Hosp c/c PRM only & 99/99 & Plasma, NOS & $\mathrm{RIA}(\mathrm{Nic})$ & RIA (DSL) \\
\hline Hankinson et al. [53] & USA & Nested c/c PRM/PSM & $397 / 620$ & HP & ELISA (DSL) & ELISA (DSL) \\
\hline Toniolo et al. [60] & USA & Nested c/c PRM/PSM & $287 / 706$ & Serum & RIA after $A C$ & RIA (in-house) \\
\hline Yu et al. [61] & China & Pop c/c PRM/PSM & $300 / 300$ & EDTA/HP & ELISA (DSL) & ELISA (DSL) \\
\hline Muti et al. [62] & Italy & Nested c/c PRM/PSM & $133 / 503$ & Serum & IRMA (DSL) & IRMA (DSL) \\
\hline Krajcik et al. [59] & USA & Nested c/c PRM/PSM & $126 / 126$ & Serum & RIA (Nic) & IRMA (DSL) \\
\hline
\end{tabular}

*For analysis inclusion, studies had to fulfil three criteria: (i) published as a full article, (ii) findings expressed as OR with 95\% Cl, (iii) association reported for at least three categories (tertiles to quintiles) of peptide levels. c/c: case-control design; PRM: pre-menopausal; PSM: postmenopausal; HP: heparin plasma sampling; EP: EDTA (ethylene diamine tetra-acetic acid) plasma; NOS: not otherwise specified; ELISA: enzymelinked immunoabsorbant assay; IRMA: immunoradiometric assay; RIA: radioimmunassay; AC: acid chromatography; DSL: Diagnostic Systems Laboratories, TX; NIC: Nichols Institute, CA. 
the lowermost and uppermost categories. These were calculated by relating the natural log of OR for different exposure levels to the reported blood concentrations (normalized to a percentile scale) using a previously described method [64]. A linear relationship between exposure and risk was assumed. The dose-response analysis confirmed that increasing IGF-I concentrations were associated with the risk of pre-menopausal breast cancer $(P<0.001)$ (Table 3 ). Similarly, an association between IGFBP-3 levels and pre-menopausal breast cancer was found $(P=0.05)$. The sizes of association for each cancer site were similar to those estimated in the baseline meta-analyses, suggesting that the assumption of linearity for the dose-response analysis was valid.

We undertook several sensitivity analyses, and with particular relevance to breast cancer, we addressed whether the inclusion criteria affected results. Specifically, our criteria excluded the large study on breast cancer risk by Kaaks et al. [65], as the analysis was based on a non-clinical definition of menopausal status, contrasting with the included breast cancer studies. When this study was included [65], the results were not materially altered.

In the correspondence arising out of this paper, Holly pointed out that menopausal status in the breast cancer studies was defined at the time of blood collection, and that some women categorized as 'pre-menopausal' breast cancer may indeed have been women sampled in pre-menopausal status, but their cancers occurred in the post-menopausal period [66]. This raises two interesting issues:

1. If there is truly no association between IGF-I, IGFBP-3 and post-menopausal breast cancer, then contamination of this group by 'pre-menopausal' women would tend to attenuate reported increased OR for pre-menopausal breast cancer.

2. Alternatively, it is conceivable that pre-menopausal women with elevated concentrations of circulating IGF-I and/or IGFBP-3 retain an increased risk of cancer into the post-menopausal age period, but currently this potential effect is too small to detect.

There is a need to determine these nuisances in future studies [67].

\section{Studies in pre-malignant breast lesions}

A Greek case-control study reported that high-IGF-I and low-IGFBP-3 circulating levels are associated with pre-menopausal breast ductal carcinoma in situ, but sample numbers were small [68]. Two other studies addressed associations with mammographic density as a risk factor for breast cancer. Within the Nurses' Health Study, Byrne et al. found that mammographic density was positively associated with plasma IGF-I levels and inversely associated

Table 2. Meta-analysis: comparisons of highest vs. lowest peptide categories for circulating IGF-I and IGFBP-3.

\begin{tabular}{lllcll}
\hline & $\begin{array}{l}\text { Number } \\
\text { of studies }\end{array}$ & Cases/controls & Summary OR (95\% CI) & P-value & Tests for heterogeneity \\
\hline $\begin{array}{l}\text { Associations with IGF-I } \\
\text { Pre-menopausal breast cancer }\end{array}$ & 6 & $660 / 1193$ & $1.93(1.38,2.69)$ & $<0.001$ & $\chi_{5}^{2}=2.5, P=0.77$ \\
Post-menopausal breast cancer & 5 & $672 / 1131$ & $0.95(0.62,1.33)$ & 0.75 & $\chi_{4}^{2}=2.7, P=0.61$ \\
Associations with IGFBP-3 & & & & & \\
Pre-menopausal breast cancer & 5 & $584 / 1088$ & $1.96(1.28,2.99)$ & 0.002 & $\chi_{4}^{2}=2.5, P=0.77$ \\
Post-menopausal breast cancer & 4 & $367 / 648$ & $0.97(0.53,1.77)$ & 0.92 & $\chi_{3}^{2}=2.7, P=0.61$ \\
\hline
\end{tabular}

Random-effects method used. Data calculated with maximally adjusted OR.

Table 3. Meta-analysis of dose-response associations with circulating IGF-I and IGFBP-3.

\begin{tabular}{|c|c|c|c|}
\hline & Number of studies & $\begin{array}{l}\text { OR comparing } 75 \text { th with } \\
\text { 25th percentile }(95 \% \mathrm{Cl})\end{array}$ & $P$-value \\
\hline \multicolumn{4}{|l|}{ Associations with IGF-I } \\
\hline Pre-menopausal breast cancer & 4 & $1.65(1.26,2.08)$ & $<0.001$ \\
\hline Post-menopausal breast cancer & 4 & $0.95(0.77,1.17)$ & 0.63 \\
\hline \multicolumn{4}{|l|}{ Associations with IGFBP-3 } \\
\hline Pre-menopausal breast cancer & 3 & $1.51(1.01,2.27)$ & 0.05 \\
\hline Post-menopausal breast cancer & 3 & $1.01(0.74,1.38)$ & 0.93 \\
\hline
\end{tabular}


with plasma IGFBP-3 levels among pre-menopausal but not post-menopausal women [69]. In a crosssectional design, Maskarinec and colleagues reported that mammographic densities were not associated with IGF-I, but there was an inverse relation with IGFBP-3 and a positive association with the IGFI/IGFBP-3 ratio among pre-menopausal women [70]. By contrast, a Canadian study has recently shown a positive trend in mean percentage of breast density by the number of $A$ alleles of the IGFBP-3 gene among pre-menopausal women; in turn, the number of $A$ alleles correlate with IGFBP-3 levels in the circulation [71]. Finally, a cross-sectional Swedish study noted that the serum IGF-I/IGFBP-3 and IGFI/IGFBP-1 ratios were elevated in pre-menopausal women with type I benign breast cysts [72].

\section{Other studies}

The search strategy in the Lancet review was to December 2002. Since then, there have been at least a further three epidemiological studies on breast cancer risk that would fulfil inclusion criteria used in our analysis. All three studies [73-75] were in relation to post-menopausal breast cancer and concur with the Lancet review's findings of no association with either IGF-I or IGFBP-3 circulating levels. By contrast, a Chinese group of investigators, who previously reported a positive association between serum IGFBP-3 and pre-menopausal breast cancer risk [61], recently reported $30-60 \%$ elevated risk of pre-menopausal breast cancer associated with homozygosity for the variant allele in polymorphisms A-202C, G227C, 5606InsA, and C5827T, functional alleles generally associated with reduced mean concentrations of circulating IGFBP-3 [76].

In addition, two meta-analyses have been published subsequent to the Lancet review, specifically examining relationships with breast cancer risk. The review reported by Shi et al. [77] used less restrictive inclusion criteria and analysed 16 publications. The meta-analysis was performed using a method known as Hedges' standardized mean differences involving the calculation of weighted mean effect sizes and their $95 \% \mathrm{Cls}$ from the reported concentrations of each peptide for each individual study. Despite these differences (and potential limitations), the findings of this review are broadly similar to our Lancet review concentrations of both total IGF-I and IGFBP-3 were positively associated with pre-menopausal breast cancer risk. The meta-analysis reported by Sugumar et al. [78] was limited to pre-menopausal breast cancer only, and used similar selection criteria to those in our review. The authors performed their meta-analysis based on six studies, and concluded that there were marginally significant associations with IGF-I concentrations, but no associations with IGFBP-3 concentrations. We attempted to repeat these analyses and discovered that there were major discrepancies between the 95\% Cls listed by Sugumar et al. and those stated within the individual studies. We reperformed the analyses using the correctly reported ORs and $95 \% \mathrm{Cls}$, and calculated very similar estimates to those reported in our Lancet paper [79].

\section{The IGFBP-3 debate}

One of the main areas of debate from the Lancet paper arises from the observation that circulating IGFBP-3 concentrations was significantly and positively associated with risk of pre-menopausal breast cancer (further debate can be found at www. christie.man.ac.uk/profinfo/department/surgery/def ualt.htm.) This goes against conventional thinking because, as pointed out above, there is a large amount of experimental literature demonstrating that IGFBP-3 is anti-proliferative and pro-apoptotic, and by implication is tumour protective. However, there are two notable laboratory studies that show IGFBP-3 as potentially tumour growth enhancing. Firstly, McCaig et al. [34] showed that, depending on the cellular environment, IGFBP-3 may be anti-apoptotic in IGFI independent Hs578T breast cells. Secondly, an authoritative French group of investigators have shown that IGFBP-3 may promote cell growth through direct stimulation of phosphatidylinositol 3-kinase in MCF-7 breast carcinoma cells, a signalling pathway that is mitogenic for these cells [80]. Within our analysis, the positive association between circulating IGFBP-3 concentrations and pre-menopausal breast cancer was among the most consistent with no evidence of statistical heterogeneity $(P=0.28)$, and for the present, these seem to be the best epidemiological data. A recent narrative review in Nature Cancer Reviews has pointed out that associations with IGFBP-3 are most inconsistent and that many issues including differences in assays, populations and other confounding factors (e.g. cigarette smoking) may be relevant [81].

\section{Other circulating IGF peptides}

A small number of studies have evaluated other components of the circulating IGF system and breast cancer risk. Li et al. [82] measured plasma-free IGF-I levels and found a marginally statistically significant increased risk of breast cancer (not categorized into pre- and post-menopausal status), and this association was independent of total IGF-I levels. However, this was a case-control design and the elevated levels of free IGF-I in the cases may reflect known aberrations of the circulating IGF system in women with 
breast cancer, such as increased IGFBP-3 proteolysis $[83,84]$.

Circulating IGFBP-1, which is inversely related to insulin concentrations and may be an acute regulator of IGF-I tissue levels [85], has been measured in three studies, but in all, there were no significant associations with breast cancer risk $[59,65,73]$. Circulating IGFBP-2, which is conventionally considered as a tumour marker [86], was measured in the above three epidemiological studies, and reported to have a significant inverse association with postmenopausal breast cancer in the Kaiser Permanente cohort [59], but not in the other two cohorts $[65,73]$.

\section{Lifestyle, nutrition and breast cancer prevention}

IGFs are influenced by nutritional and lifestyle factors, which in turn are risk factors for many nonsmoking-related cancers [87]. For the first time, our systematic review demonstrated that the associations between IGF-I, IGFBP-3 and cancer risk vary by cancer site [56]. In turn, cigarette smoking is associated with a reduction in mean serum IGFBP-3 levels, and to a lesser extent, IGF-I levels [81]. Specifically, the findings of the Lancet review suggest that circulating IGF-I levels are positively associated with the risk of non-smoking-related malignancies namely, prostate, colorectal and pre-menopausal breast. These cancers are variably associated with energy-related factors such as body mass index (BMI), physical activity and growth in early life [88]. As IGF-I is an energy-related peptide, it is tempting to speculate that it is a key link between these risk factors and disease, but the relationships are complex. In adulthood, IGF-I is related to BMI in a nonlinear manner - low levels in low BMI, increases thereafter with increasing BMI, but decreases again in obesity (probably due to blunted growth hormone secretion) [8]. Similarly, circulating IGF-I levels tend to be inversely related to physical activity $[89,90]$, but the relationship may be dependent on longterm fitness status [89]. Interventional studies have reported variable relationships between physical training and IGFBP-3 concentrations [89,90]. During adolescence, circulating IGF-I levels are highly correlated with growth and body height, but are less strong in adulthood [19]. Circulating IGF-I concentrations appear unrelated to lung cancer risk, which would be predicted, as this malignancy is weakly associated with energy-related factors. Increasingly studies also show that certain dietary factors, themselves cancer risk factors, increase IGF-I levels like milk [91], increased red meat consumption [6] and zinc [92], while others like tomato juice (containing lycopene) [93] reduce IGF-I levels in the circulation.
Paradoxically, soya protein, thought to be protective for breast cancer, is associated with increased levels of serum total IGF-I [94].

In addition, the GH-IGF-I axis is highly responsive to extremes of nutritional status and this may be involved as one of the underlying mechanisms through which caloric restriction may affect cancer risk $[95,96]$. However, across general populations, studies evaluating the relationship between total energy intake and circulating IGF peptide concentrations have reported a positive association with plasma IGF-I, and an inverse association with plasma IGFBP-3, in one US study [6], but no associations with the two peptides in cohorts from the UK [93,97], Singapore [94], Hawaii [7] and the Netherlands [98]. However of particular interest to early life events and breast cancer risk, in a group of 87 post-menopausal women, Elias et al. [99] found that childhood exposure to the 1944-1945 Dutch famine was associated with increased plasma levels of IGF-I and IGFBP-3, whereas IGFBP-1 and -2 levels were weakly decreased. These results are opposite to immediate responses seen under starvation and the authors hypothesize that this could indicate a permanent overshoot upon improvement of nutritional status after the famine.

A further paradox is the observation that postmenopausal breast cancer is associated with adiposity, insulin resistance and the metabolic syndrome [100], yet these same factors are risk factors for cardiovascular disease and type 2 diabetes mellitus, and in turn, the former is associated with low levels of circulating IGF-I [101,102], while the latter is predicted by a complex interaction of IGFBP-1 levels and low-IGF-I circulating concentrations [103]. It is tempting to speculate that a woman's circulating level of IGF-I may have greatest important for cancer risk prior to the menopausal, and for risk of cardiovascular disease and/or diabetes, thereafter.

\section{Implications and public health}

The findings of this review suggest that circulating IGF-I and IGFBP-3 may be of potential importance for cancer risk assessment and prevention. The use of IGF-I and IGFBP-3 measurements as surrogate markers of response to prevention interventions is currently being piloted [104,105]. Taken together, cancers of the prostate, colorectal, breast, and lung account for over two million new cases in developed countries per annum [106]. As the evidence to date has typically been based on risk for the upper quartile of a population, the contribution of altered levels of IGFs to the burden of cancer may be considerable. As the measurement of serum total IGF-I is relatively easy to perform and inexpensive, there is 
scope to draw parallels with the measurement of serum cholesterol and cardiovascular disease risk. A further analogy is that the IGF peptides exist as an expanded family within the circulation, and with the availability of reliable assays to measure free IGF-I [107], IGFBP-1/IGF-I binary complexes [108], and IGFBP-3 proteolytic activity [109], it may be possible to build up an 'IGF serum profile' for individuals that may enhance cancer risk assessment. Short of examples of expensive and labour intensive proteomic assessments [110], there are few examples of a promising 'blood test' for cancer risk assessment.

\section{Conclusions}

There is now considerable evidence from human and laboratory studies supporting the hypothesis that circulating levels of IGF-I and IGFBP-3 influence the development of common cancer, of which increased risk of pre-menopausal breast cancer is now established. It is becoming increasing important that the clinical breast oncologist understands the physiology of the IGF system and its potential role in cancer risk assessment and prevention.

\section{Potential conflicts of interest}

A.G.R. and S.M.S. have received hospitality from Diagnostic Systems Laboratories, and from several pharmaceutical companies that make human growth hormone. A.G.R. has received a lecture honorarium from Eli-Lilly. S.M.S. receives research funding from Pfizer, Novo Nordisk and Novartis.

\section{References}

1. Cohen P, Clemmons DR, Rosenfeld RG. Does the GH-IGF axis play a role in cancer pathogenesis? Growth Horm IGF Res 2000; 10: 297-305.

2. Khandwala HM, McCutcheon IE, Flyvbjerg A, Friend KE. The effects of insulin-like growth factors on tumorigenesis and neoplastic growth. Endocr Rev 2000; 21: 215-244.

3. $\mathrm{Yu} \mathrm{H}$, Rohan T. Role of the insulin-like growth factor family in cancer development and progression. $J$ Natl Cancer Inst 2000; 92: 1472-1489.

4. Pollak M. Insulin-like growth factor physiology and cancer risk. Eur J Cancer 2000; 36: 1224-1228.

5. Leung KC, Johannsson G, Leong GM, Ho KK. Estrogen regulation of growth hormone action. Endocr Rev 2004; 25: 693-721.

6. Holmes MD, Pollak MN, Willett WC, Hankinson SE. Dietary correlates of plasma insulin like growth factor I and insulin-like growth factor binding protein 3 concentrations. Cancer Epidemiol Biomarker Prev 2002; 11: 852-861.

7. DeLellis K, Rinaldi S, Kaaks RJ, et al. Dietary and lifestyle correlates of plasma insulin-like growth factor-I (IGF-I) and IGF binding protein-3 (IGFBP-3): the multiethnic cohort. Cancer Epidemiol Biomarker Prev 2004; 13: 1444-1451.

8. Lukanova A, Soderberg S, Stattin P, et al. Nonlinear relationship of insulin-like growth factor (IGF)-I and IGFI/IGF-binding protein-3 ratio with indices of adiposity and plasma insulin concentrations (Sweden). Cancer Causes Contr 2002; 13: 509-516.

9. Kaaks R, Lukanova A. Effects of weight control and physical activity in cancer prevention: role of endogenous hormone metabolism. Ann NY Acad Sci 2002; 963: 268-281.

10. Copeland JL, Chu SY, Tremblay MS. Aging, physical activity, and hormones in women - a review. J Aging Phys Act 2004; 12: 101-116.

11. Jerome L, Shiry L, Leyland-Jones B. Anti-insulin-like growth factor strategies in breast cancer. Semin Oncol 2004; 31(1 Suppl 3): 54-63.

12. Byron SA, Yee D. Potential therapeutic strategies to interrupt insulin-like growth factor signaling in breast cancer. Semin Oncol 2003; 30(5 Suppl 16): 125-132.

13. Jones JI, Clemmons DR. Insulin-like growth factors and their binding proteins: biological actions. Endocr Rev 1995; 16: 3-34.

14. Clemmons DR. Insulin-like growth factor binding proteins and their role in controlling IGF actions. Cytokine Growth Factor Rev 1997; 8: 45-62.

15. Rajaram S, Baylink DJ, Mohan S. Insulin-like growth factor-binding proteins in serum and other biological fluids: regulation and functions. Endocr Rev 1997; 18: 801-831.

16. Martin JL, Baxter RC. Insulin-like growth factor-binding protein from human plasma. Purification and characterization. J Biol Chem 1986; 261: 8754-8760.

17. Baxter RC. Insulin-like growth factor (IGF) binding proteins: the role of serum IGFBPs in regulating IGF availability. Acta Paediatr Scand Supp/ 1991; 372: 107-114.

18. Zapf J. Physiological role of the insulin-like growth factor binding proteins. Eur J Endocrinol 1995; 132: 645-654.

19. Juul A, Bang P, Hertel NT, et al. Serum insulin-like growth factor-I in 1030 healthy children, adolescents, and adults: relation to age, sex, stage of puberty, testicular size, and body mass index. J Clin Endocrinol Metab 1994; 78: 744-752.

20. Renehan AG. Gender differences in long-term survival of patients with colorectal cancer. Br J Surg 2002; 89: 489-490.

21. Thissen JP, Ketelslegers JM, Underwood LE. Nutritional regulation of the insulin-like growth factors. Endocr Rev 1994; 15: 80-101.

22. Dupont J, Pierre A, Froment P, Moreau C. The insulin-like growth factor axis in cell cycle progression. Horm Metab Res 2003; 35: 740-750.

23. Baserga R, Resnicoff M, D'Ambrosio C, Valentinis B. The role of the IGF-I receptor in apoptosis. Vitam Horm 1997; 53: 65-98.

24. Fukuda R, Hirota K, Fan F, et al. Insulin-like growth factor 1 induces hypoxia-inducible factor 1-mediated vascular endothelial growth factor expression, which is dependent on MAP kinase and phosphatidylinositol 3-kinase signaling in colon cancer cells. J Biol Chem 2002; 277: 38205-38211.

25. Andre F, Rigot V, Thimonier J, et al. Integrins and E-cadherin cooperate with IGF-I to induce migration of epithelial colonic cells. Int J Cancer 1999; 83: 497-505. 
26. Playford MP, Bicknell D, Bodmer WF, Macaulay VM. Insulin-like growth factor 1 regulates the location, stability, and transcriptional activity of beta-catenin. Proc NatI Acad Sci USA 2000; 97: 12103-12108.

27. Dupont J, Le Roith D. Insulin-like growth factor 1 and oestradiol promote cell proliferation of MCF-7 breast cancer cells: new insights into their synergistic effects. Mol Pathol 2001; 54: 149-154.

28. Firth SM, Baxter RC. Cellular actions of the insulin-like growth factor binding proteins. Endocr Rev 2002; 23: 824-854.

29. Baxter RC. Signalling pathways involved in antiproliferative effects of IGFBP-3: a review. Mol Pathol 2001; 54: 145-148.

30. Ricort JM, Binoux M. Insulin-like growth factor (IGF) binding protein-3 inhibits type 1 IGF receptor activation independently of its IGF binding affinity. Endocrinology 2001; 142: 108-113.

31. Fowler CA, Perks CM, Newcomb PV, et al. Insulin-like growth factor binding protein-3 (IGFBP-3) potentiates paclitaxel-induced apoptosis in human breast cancer cells. Int J Cancer 2000; 88: 448-453.

32. Cohen P, Lamson G, Okajima T, Rosenfeld RG. Transfection of the human IGFBP-3 gene into Balb/c fibroblasts: a model for the cellular functions of IGFBPs. Growth Regul 1993; 3: 23-26.

33. Rajah $R$, Valentinis $B$, Cohen $P$. Insulin-like growth factor (IGF)-binding protein-3 induces apoptosis and mediates the effects of transforming growth factor-beta1 on programmed cell death through a p53- and IGF-independent mechanism. J Biol Chem 1997; 272: 12181-12188.

34. McCaig C, Perks CM, Holly JM. Intrinsic actions of IGFBP-3 and IGFBP-5 on Hs578T breast cancer epithelial cells: inhibition or accentuation of attachment and survival is dependent upon the presence of fibronectin. J Cell Sci 2002; 115: 4293-4303.

35. Gui Y, Murphy LJ. Insulin-like growth factor (IGF)-binding protein-3 (IGFBP-3) binds to fibronectin (FN): demonstration of IGF-I/IGFBP-3/fn ternary complexes in human plasma. J Clin Endocrinol Metab 2001; 86: 2104-2110.

36. Fowlkes JL, Serra DM. Characterization of glycosaminoglycan-binding domains present in insulin-like growth factor-binding protein-3. J Biol Chem 1996; 271: 14676-14679.

37. Liu B, Lee HY, Weinzimer SA, et al. Direct functional interactions between insulin-like growth factor-binding protein- 3 and retinoid $X$ receptor-alpha regulate transcriptional signaling and apoptosis. J Biol Chem 2000; 275: 33607-33613.

38. Butt AJ, Martin JL, Dickson KA, et al. Insulin-like growth factor binding protein-3 expression is associated with growth stimulation of T47D human breast cancer cells: the role of altered epidermal growth factor signaling. J Clin Endocrinol Metab 2004; 89: 1950-1956.

39. Buckbinder L, Talbott $\mathrm{R}$, Velasco Miguel $\mathrm{S}$, et al. Induction of the growth inhibitor IGF-binding protein 3 by p53. Nature 1995; 377: 646-649.

40. Butt AJ, Firth SM, King MA, Baxter RC. Insulin-like growth factor-binding protein-3 modulates expression of $\mathrm{Bax}$ and $\mathrm{Bcl}-2$ and potentiates p53-independent radiation-induced apoptosis in human breast cancer cells. J Biol Chem 2000; 275: 39174-39181.

41. Kim HS, Ingermann AR, Tsubaki J, et al. Insulin-like growth factor-binding protein 3 induces caspase-dependent apoptosis through a death receptor-mediated pathway in MCF-7 human breast cancer cells. Cancer Res 2004; 64: 2229-2237.

42. Ibrahim YH, Yee D. Insulin-like growth factor-I and cancer risk. Growth Horm IGF Res 2004; 14: 261-269.

43. Desbois-Mouthon C, Cadoret A, Blivet-Van Eggelpoel MJ, et al. Insulin and IGF-1 stimulate the beta-catenin pathway through two signalling cascades involving GSK3beta inhibition and Ras activation. Oncogene 2001; 20 : 252-259.

44. Helle SI. The insulin-like growth factor system in advanced breast cancer. Best Pract Res Clin Endocrinol Metab 2004; 18: 67-79.

45. Turner BC, Haffty BG, Narayanan L, et al. Insulin-like growth factor-I receptor overexpression mediates cellular radioresistance and local breast cancer recurrence after lumpectomy and radiation. Cancer Res 1997; 57: 3079-3083.

46. Guvakova MA, Surmacz E. Tamoxifen interferes with the insulin-like growth factor I receptor (IGF-IR) signaling pathway in breast cancer cells. Cancer Res 1997; 57: 2606-2610.

47. Lu Y, Zi X, Zhao Y, et al. Insulin-like growth factor-I receptor signaling and resistance to trastuzumab (Herceptin). J Natl Cancer Inst 2001; 93: 1852-1857.

48. Zhang X, Yee D. Tyrosine kinase signalling in breast cancer: insulin-like growth factors and their receptors in breast cancer. Breast Cancer Res 2000; 2: 170-175.

49. O'Connor R. Regulation of IGF-I receptor signaling in tumor cells. Horm Metab Res 2003; 35: 771-777.

50. Baxter RC. What is the significance of IGF-binding protein-3 proteolysis in the circulation? J Clin Endocrinol Metab 2001; 86: 5087-5088.

51. Modric T, Silha JV, Shi Z, et al. Phenotypic manifestations of insulin-like growth factor-binding protein-3 overexpression in transgenic mice. Endocrinology 2001; 142: 1958-1967.

52. Chan JM, Stampfer MJ, Giovannucci E, et al. Plasma insulin-like growth factor-I and prostate cancer risk: a prospective study. Science 1998; 279: 563-566.

53. Hankinson SE, Willett WC, Colditz GA, et al. Circulating concentrations of insulin-like growth factor-I and risk of breast cancer. Lancet 1998; 351: 1393-1396.

54. Ma J, Pollak MN, Giovannucci E, et al. Prospective study of colorectal cancer risk in men and plasma levels of insulin-like growth factor (IGF)-I and IGFbinding protein3. J Natl Cancer Inst 1999; 91: 620-625.

55. Yu H, Spitz MR, Mistry J, et al. Plasma levels of insulinlike growth factor-I and lung cancer risk: a case-control analysis. J Natl Cancer Inst 1999; 91: 151-156.

56. Renehan AG, Zwahlen M, Minder C, et al. Insulin-like growth factor (IGF)-I, IGF binding protein-3, and cancer risk: systematic review and metaregression analysis. Lancet 2004; 363: 1346-1353.

57. Moher D, Cook DJ, Eastwood S, et al. Improving the quality of reports of meta-analyses of randomised controlled trials: the QUOROM statement. Quality of reporting of meta-analyses. Lancet 1999; 354: 1896-1900.

58. Del Giudice ME, Fantus IG, Ezzat S, et al. Insulin and related factors in premenopausal breast cancer risk. Breast Cancer Res Treat 1998; 47: 111-120.

59. Krajcik RA, Borofsky ND, Massardo S, Orentreich N. Insulin-like growth factor I (IGF-I), IGF-binding proteins, 
and breast cancer. Cancer Epidemiol Biomarker Prev 2002; 11: 1566-1573.

60. Toniolo P, Bruning PF, Akhmedkhanov A, et al. Serum insulin-like growth factor-I and breast cancer. Int $J$ Cancer 2000; 88: 828-832.

61. Yu H, Jin F, Shu XO, et al. Insulin-like growth factors and breast cancer risk in Chinese women. Cancer Epidemiol Biomarker Prev 2002; 11: 705-712.

62. Muti P, Quattrin T, Grant BJ, et al. Fasting glucose is a risk factor for breast cancer: a prospective study. Cancers Epidemiol Biomarker Prev 2002; 11: 1361-1368.

63. DerSimonian R, Laird N. Meta-analysis in clinical trials. Control Clin Trials 1986; 7: 177-188.

64. Greenland S, Longnecker MP. Methods for trend estimation from summarized dose response data, with applications to meta-analysis. Am J Epidemiol 1992; 135: 1301-1309.

65. Kaaks R, Lundin E, Rinaldi S, et al. Prospective study of IGF-I, IGF-binding proteins, and breast cancer risk, in northern and southern Sweden. Cancer Causes Contr 2002; 13: 307-316.

66. Holly J. IGF-1, IGFBP-3, and cancer risk. Lancet 2004; 364: 325-326.

67. Renehan AG, Zwahlen M, O'Dwyer ST, et al. IGF-1, IGFBP-3, and cancer risk. Lancet 2004; 364: 326-327.

68. Bohlke K, Cramer DW, Trichopoulos D, Mantzoros CS. Insulin-like growth factor-I in relation to premenopausal ductal carcinoma in situ of the breast. Epidemiology 1998; 9: 570-573.

69. Byrne C, Colditz GA, Willett WC, et al. Plasma insulinlike growth factor (IGF) I, IGF-binding protein 3, and mammographic density. Cancer Res 2000; 60: 3744-3748.

70. Maskarinec G, Williams AE, Kaaks R. A cross-sectional investigation of breast density and insulin-like growth factor I. Int J Cancer 2003; 107: 991-996.

71. Lai JH, Vesprini $\mathrm{D}$, Zhang $\mathrm{W}$, et al. A polymorphic locus in the promoter region of the IGFBP3 gene is related to mammographic breast density. Cancer Epidemiol Biomarker Prev 2004; 13: 573-582.

72. Enriori PJ, Fischer CR, Gori JR, et al. Augmented serum levels of the IGF-I/IGF-binding protein-3 ratio in pre-menopausal patients with type I breast cysts. Eur $J$ Endocrinol 2003; 148: 177-184.

73. Keinan-Boker L, Bueno De Mesquita HB, Kaaks R, et al. Circulating levels of insulin-like growth factor I, its binding proteins-1, -2, -3, C-peptide and risk of postmenopausal breast cancer. Int $J$ Cancer 2003; 106: 90-95.

74. Hirose $\mathrm{K}$, Toyama $\mathrm{T}$, Iwata $\mathrm{H}$, et al. Insulin, insulin-like growth factor-I and breast cancer risk in Japanese women. Asian Pac J Cancer Prev 2003; 4: 239-246.

75. Schairer C, Hill D, Sturgeon SR, et al. Serum concentrations of IGF-I, IGFBP-3 and C-peptide and risk of hyperplasia and cancer of the breast in postmenopausal women. Int J Cancer 2004; 108: 773-779.

76. Ren Z, Cai Q, Shu XO, et al. Genetic polymorphisms in the IGFBP3 gene: association with breast cancer risk and blood IGFBP-3 protein levels among Chinese women. Cancer Epidemiol Biomarker Prev 2004; 13: 1290-1295.

77. Shi R, Yu H, McLarty J, Glass J. IGF-I and breast cancer: a meta-analysis. Int J Cancer 2004; 111: 418-423.

78. Sugumar A, Liu YC, Xia Q, Koh YS, Matsuo K. Insulin-like growth factor (IGF)-I and IGF binding protein 3 and the risk of premenopausal breast cancer: a meta-analysis of literature. Int J Cancer 2004; 111: 293-297.

79. Renehan AG, Egger M, Minder $C$, et al. Insulin-like growth factor (IGF)-I, IGF binding protein-3, and breast cancer risk: comparisons of three metaanalyses [letter]. Int J Cancer 2004; 111 (in press).

80. Ricort JM, Binoux M. Insulin-like growth factor binding protein-3 stimulates phosphatidylinositol 3-kinase in MCF-7 breast carcinoma cells. Biochem Biophys Res Commun 2004; 314: 1044-1049.

81. Renehan AG, Atkin WS, O'Dwyer ST, Shalet SM. The effect of cigarette smoking use and cessation on serum insulin-like growth factors. $\mathrm{Br} J$ Cancer 2004; 91: 1525-1531.

82. Li BD, Khosravi MJ, Berkel HJ, et al. Free insulin-like growth factor-I and breast cancer risk. Int J Cancer 2001; 91: 736-739.

83. Helle SI, Holly JM, Tally M, et al. Influence of treatment with tamoxifen and change in tumor burden on the IGFsystem in breast cancer patients. Int $J$ Cancer 1996; 69: 335-339.

84. Gronbaek H, Tanos V, Meirow D, et al. Effects of tamoxifen on insulin-like growth factors, IGF binding proteins and IGFBP-3 proteolysis in breast cancer patients. Anticancer Res 2003; 23: 2815-2820.

85. Frystyk J. Free insulin-like growth factors - measurements and relationships to growth hormone secretion and glucose homeostasis. Growth Horm IGF Res 2004; 14: 337-375.

86. Renehan AG, Jones J, Potten CS, Shalet SM, O' Dwyer ST. Elevated serum insulin-like growth factor (IGF)-II and IGF binding protein-2 in patients with colorectal cancer. $\mathrm{Br} J$ Cancer 2000; 83: 1344-1350.

87. Giovannucci E. Nutrition, insulin, insulin-like growth factors and cancer. Horm Metab Res 2003; 35: 694-704.

88. Bianchini F, Kaaks R, Vainio H. Overweight, obesity, and cancer risk. Lancet Oncol 2002; 3: 565-574.

89. Rosendal L, Langberg H, Flyvbjerg A, et al. Physical capacity influences the response of insulin-like growth factor and its binding proteins to training. J Appl Physiol 2002; 93: 1669-1675.

90. Fairey AS, Courneya KS, Field CJ, et al. Effects of exercise training on fasting insulin, insulin resistance, insulinlike growth factors, and insulin-like growth factor binding proteins in postmenopausal breast cancer survivors: a randomized controlled trial. Cancer Epidemiol Biomarker Prev 2003; 12: 721-727.

91. Ma J, Giovannucci E, Pollak M, et al. Milk intake, circulating levels of insulin-like growth factor-I, and risk of colorectal cancer in men. J Natl Cancer Inst 2001; 93: 1330-1336.

92. Devine A, Rosen C, Mohan S, Baylink D, Prince RL. Effects of zinc and other nutritional factors on insulin-like growth factor I and insulin-like growth factor binding proteins in postmenopausal women. Am J Clin Nutr 1998; 68: 200-206.

93. Gunnell D, Oliver SE, Peters TJ, et al. Are diet-prostate cancer associations mediated by the IGF axis? A crosssectional analysis of diet, IGF-I and IGFBP-3 in healthy middle-aged men. Br J Cancer 2003; 88: 1682-1686.

94. Probst-Hensch NM, Wang $\mathrm{H}$, Goh VH, et al. Determinants of circulating insulin-like growth factor I and insulin-like growth factor binding protein 3 concentrations in a cohort of Singapore men and women. Cancer Epidemiol Biomarker Prev 2003; 12: 739-746. 
95. Dunn SE, Kari FW, French J, et al. Dietary restriction reduces insulin-like growth factor I levels, which modulates apoptosis, cell proliferation, and tumor progression in p53-deficient mice. Cancer Res 1997; 57: 4667-4672.

96. Hursting SD, Lavigne JA, Berrigan D, et al. Dietgene interactions in p53-deficient mice: insulin-like growth factor-1 as a mechanistic target. $J$ Nutr 2004; 134: 2482S-2486S.

97. Allen NE, Appleby PN, Kaaks R, et al. Lifestyle determinants of serum insulin-like growth-factor-I (IGF-I), C-peptide and hormone binding protein levels in British women. Cancer Causes Contr 2003; 14: 65-74.

98. Vrieling A, Voskuil DW, Mesquita HB, et al. Dietary determinants of circulating insulin-like growth factor (IGF)-I and IGF binding proteins $1,-2$ and -3 in women in the Netherlands. Cancer Causes Contr 2004; 15: 787-796.

99. Elias SG, Keinan-Boker L, Peeters PH, et al. Long term consequences of the 1944-1945 Dutch famine on the insulin-like growth factor axis. Int J Cancer 2004; 108(4): 628-630.

100. Manjer J, Kaaks R, Riboli E, Berglund G. Risk of breast cancer in relation to anthropometry, blood pressure, blood lipids and glucose metabolism: a prospective study within the Malmo Preventive Project. Eur J Cancer Prev 2001; 10(1): 33-42.

101. Juul A, Scheike T, Davidsen M, Gyllenborg J, Jorgensen T. Low serum insulin-like growth factor I is associated with increased risk of ischemic heart disease: a population-based case-control study. Circulation 2002; 106: 939-944.

102. Laughlin GA, Barrett-Connor E, Criqui MH, KritzSilverstein $D$. The prospective association of serum insulin-like growth factor I (IGF-I) and IGF-binding protein-1 levels with all cause and cardiovascular disease mortality in older adults: the Rancho Bernardo Study. J Clin Endocrinol Metab 2004; 89: 114-120.

103. Sandhu MS, Heald AH, Gibson JM, et al. Circulating concentrations of insulin-like growth factor-I and development of glucose intolerance: a prospective observational study. Lancet 2002; 359: 1740-1745.

104. McTiernan A. Intervention studies in exercise and cancer prevention. Med Sci Sports Exerc 2003; 35: 1841-1845.

105. Harvie M, Mercer T, Humphries G, Adams J, Howell A. The effects of weight loss and exercise on biomarkers of breast cancer risk - rationale and study design. Recent Res Develop Nutr 2002; 5: 91-110.

106. WHO/International Agency for Research on Cancer. World Cancer Report. Stewart BW, Kleihues P (Eds). Lyon: IARC Press; 2003.

107. Frystyk J, Skjaerbaek C, Dinesen B, Orskov H. Free insulin-like growth factors (IGF-I and IGF-II) in human serum. FEBS Lett 1994; 348: 185-191.

108. Frystyk J, Hojlund K, Rasmussen KN, et al. Development and clinical evaluation of a novel immunoassay for the binary complex of IGF-I and IGF-binding protein-1 in human serum. J Clin Endocrinol Metab 2002; 87: 260-266.

109. Diamandi A, Mistry J, Krishna RG, Khosravi J. Immunoassay of insulin-like growth factor binding protein-3 (IGFBP-3): new means to quantifying IGFBP-3 proteolysis. J Clin Endocrinol Metab 2000; 85: 2327-2333.

110. Petricoin EF, Ardekani AM, Hitt BA, et al. Use of proteomic patterns in serum to identify ovarian cancer. Lancet 2002; 359: 572-577. 